zeszyt 155, 2018, 27-45

doi: 10.4467/20833113PG.18.016.9539

Instytut Geografii i Gospodarki Przestrzennej UJ

Wydawnictwo Uniwersytetu Jagiellońskiego

\title{
ZRÓŻNICOWANIE I ZMIENNOŚĆ WIELOLETNIA SEZONOWOŚCI PRZEPEYWU W WYBRANYCH PRZEKROJACH WODOWSKAZOWYCH WISŁY
}

\author{
Pawet Jokiel, Przemystaw Tomalski
}

\section{Differentiation of river flow seasonality and its multiannual changeability in selected cross-sections on the Vistula river}

Abstract:The aim of the study is to identify the flow seasonality of the Vistula river in 14 water-gauge cross-sections located along the river course (from Skoczów to Tczew). For this purpose, the following characteristics were used: seasonality index (IS), period of seasonal concentration (PK) half-flow date (TPO), and concentration index (GMO). Hydrometric data from the 1951-2016 period were shared by IMGW-PIB. The average time of seasonal concentrations and half-flow dates in the analysed cross-sections occurred in April or May. Along the Vistula river the mean PK and TPO regress towards winter (are earlier and earlier). The average seasonality index is comprised in the range $22-32 \%$, while the values of the concentration index fall into the range 10.0-14.5. The highest IS values characterize the upper part of the river down to the Goczałkowice water-gauge (here it reaches the maximum). Next the IS rapidly decreases, due to the summing of the flows from the Vistula river tributaries varying conditions of flow formation (from Carpathian Mountains and Uplands). A significant increase in the IS is visible below the mouths of the Dunajec and then the San rivers. A local maximum of the seasonality index occurs in the Zawichost cross-section. Next, the IS slowly decreases along the river down to the Vistula river mouth. One exception is the Włocławek water-gauge where a small increase of the IS can be noticed. It is due to the functioning of a dam and a big reservoir in the town. The changes of the concentration index along the Vistula river are similar to the seasonality index changes but the differences between the values of extremes are less visible.

In the five analysed flood years, both the seasonality indexes and the concentration indexes were quite high in the upper part of the Vistula river and average in the central and lower parts of the river. The half-flow dates and the periods of seasonal concentration were stable along the whole river's course but very diversified in particular years. The changes of the 
examined seasonality characteristics in dry years were very similar to analogical changes in normal years. Only in 1959 was the situation different when the IS was very low and the PK and TPO occured later and later down the river's course.

Keywords: the Vistula river, seasonality changes, river flow

Zarys treści: Celem pracy jest identyfikacja sezonowości przepływu Wisły w 14 przekrojach wodowskazowych zlokalizowanych wzdłuż jej biegu (od Skoczowa po Tczew). Wykorzystano w tym celu indeks sezonowości IS oraz wskaźnik pory koncentracji PK, wskaźnik sezonowości odpływu GMO oraz termin połowy odpływu TPO. Dane hydrometryczne udostępnione zostały przez IMGW-PIB i pochodzą z wielolecia 1951-2016. Przeciętne wskaźniki pory koncentracji i termin połowy odpływu przypadają w analizowanych przekrojach wodowskazowych w kwietniu lub maju. $Z$ biegiem Wisły przeciętne PK i TPO cofają się w kierunku zimy (są coraz wcześniejsze). Przeciętne indeksy sezonowości IS zawierają się w granicach 22-32\%, podczas gdy wskaźniki sezonowości odpływu GMO 10,0-14,5. Najwyższymi indeksami sezonowości cechuje się górski odcinek Wisły aż po wodowskaz w Goczałkowicach (tu IS osiąga maksimum). Następnie wskaźnik ten gwałtownie maleje, co wynika z sumowania się w Wiśle dopływów z cieków o zróżnicowanych warunkach formowania się odpływu (karpackich i wyżynnych). Wyraźny wzrost IS widoczny jest ponownie poniżej ujścia Dunajca, a później Sanu. W Zawichoście IS osiąga lokalne maksimum. W dalszym biegu Wisły IS nieznacznie maleje aż do ujścia. Wyjątek stanowi tu przekrój wodowskazowy we Włocławku, na którym zaznacza się nieznaczny wzrost indeksu sezonowości związany z funkcjonowaniem zbiornika zaporowego. Zmiany wskaźnika sezonowości odpływu (GMO) z biegiem Wisły są podobne do zmian IS, przy czym różnice między ekstremami są słabiej zaznaczone. W pięciu analizowanych latach powodziowych indeksy (IS) i wskaźniki sezonowości (GMO) były dość wysokie w górnym biegu Wisły oraz przeciętne w środkowym i dolnym jej biegu. Terminy pory koncentracji (PK) i połowy odpływu (TPO) były dość stabilne w całym biegu rzeki, choć bardzo zróżnicowane w obrębie wybranych lat. $\mathrm{W}$ dwu $\mathrm{z}$ trzech lat suchych zmiany badanych miar sezonowości z biegiem Wisły były podobne jak w warunkach przeciętnych. Różnice wystąpiły w 1959 r., w którym IS były bardzo wysokie, a PK i TPO w coraz niżej położonych przekrojach - coraz późniejsze.

Stowa kluczowe: Wisła, zmiany sezonowości, przepływ

\section{Uwagi wstępne}

Podpisany w 1466 r. II pokój toruński przywrócił Królestwu Polskiemu Pomorze Gdańskie, a tym samym „udrożnił” Wisłę do Gdańska. Rok później Wisłą popłynęły do Bałtyku łodzie i tratwy pierwszego wolnego flisu. Wydarzenie to stało się w 2016 r. przesłanką do ustanowienia przez Sejm Rzeczypospolitej roku 2017 Rokiem Rzeki Wisły. W roku tym w całym kraju odbyły się setki różnych imprez informacyjnych, naukowych, społecznych, kulturowych promujących Wisłę. Uczestniczyli w nich mieszkańcy nadwiślańskich społeczności, politycy, działacze społeczni i wreszcie naukowcy, wśród których nie brakowało hydrologów, którzy na różnych spotkaniach prezentowali swoje najnowsze osiągnięcia w zakresie lepszego poznania królowej 
naszych rzek i jej dorzecza. Prezentowany niżej artykuł wpisuje się właśnie w tę problematykę.

Ażeby dosiegnać Battyku, Wista musiata utorować sobie drog̨ przez oba pasma wyżyn...,

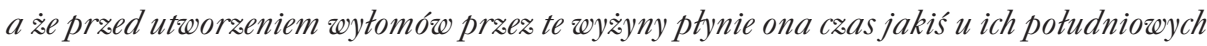
podnóży..., więc wskutek tego otrzymata ksztatt esowaty, przyczem ujście przypadto pod tym samym potudnikiem, co i śródta. Wskutek wygięć rzeczywista dtugość Wisty stata sie dwa razy większq od linii prostej, taczqcej źródta * ujściem. Tak o Wiśle pisał w 1893 r. Wacław Nałkowski w Zarysie Geografii Powszechnej (str. 434).

Za początek Wisły uznaje się źródełka Czarnej i Białej Wisełki, sączące się z północnych stoków Baraniej Góry w Beskidzie Śląskim, na wysokości ok. 1116 m n.p.m. Natomiast ujściem rzeki jest ukończony w 1895 r. sztuczny, obwałowany przekop pod Świbnem, który wykonano wzdłuż starego koryta jednej z odnóg Wisły, tzw. Przemysławy. Długość przekopu osiąga 7,1 km, a maksymalna szerokość $400 \mathrm{~m}$. Dzisiejsza długość Wisły wynosi 1047 km, a powierzchnia jej dorzecza ok. 194424 km² (169 tys. $\mathrm{km}^{2}$ w Polsce; 54\% powierzchni kraju).

Pierwszy najdłuższy, bo prawie 400-kilometrowy, odcinek Wisły (do ujścia Sanu), zwany jest Górną Wisłą. Rzeka odbiera tu wodę z najzasobniejszego w tym względzie obszaru Polski - zlewni Górnej Wisły (ok. 30\% zasobów wodnych kraju). Do Polski należy 45,9 tys. $\mathrm{km}^{2}$ tego fragmentu dorzecza. Jego najważniejszą część stanowią Beskidy Zachodnie i Wschodnie, odwadniane przez kilkanaście dużych systemów rzek górskich (np. Soły, Skawy, Raby, Dunajca, Sanu i wielu innych) o deszczowo-śnieżnym i śnieżno-deszczowym reżimie oraz znaczny fragment wyżyn środkowopolskich, drenowany przez kilkanaście rzek wyżynnych (np. Przemszę, Szreniawę, Nidę, Tanew i inne) o ustroju śnieżnym słabo i średnio wykształconym oraz znacznym udziale zasilania podziemnego. Z uwagi na fakt, że uznaje się Wisłę za rzekę żeglowną dopiero od ujścia Przemszy, ten właśnie przekrój stanowi punkt zerowy w jej kilometrażu. Odcinek tzw. Małej Wisły w przybliżeniu zamyka przekrój wodowskazowy w Nowym Bieruniu.

Poniżej ujścia Sanu (w przybliżeniu jest to przekrój wodowskazowy w Zawichoście) rozpoczyna się środkowy, 256-kilometrowy bieg Wisły, który kończy się poniżej ujścia Narwi (nieco powyżej przekroju wodowskazowego w Kępie Polskiej). Powierzchnia tej części dorzecza Wisły wynosi ok. 98,9 tys. km² (51\% dorzecza Wisły), z czego 88,8 tys. $\mathrm{km}^{2}$ znajduje się w Polsce. W zasilaniu tego odcinka Wisły dominuje prawa, w większości nizinna, część jej zlewni (83,4\% całości), którą odwadniają: Wieprz, Bug oraz Narew z Biebrzą, a więc rzeki o kontynentalnych cechach reżimu oraz zasilaniu śnieżnym silnie i średnio wykształconym. Dopływy lewe są hydrologicznie mniej istotne, przy czym największe z nich: Kamienna, Radomka i Pilica mają wszelkie cechy rzek wyżynnych i reżim śnieżny zwykle średnio, a rzadziej silnie wykształcony. Warto podkreślić, że jeśli Narew uznać za dopływ Bugu, to długość tego ostatniego będzie większa od długości Wisły w miejscu ich połączenia. 
Dolna Wisła rozpoczyna się poniżej ujścia Narwi i odcinek do ujścia liczy $391 \mathrm{~km}$. Powierzchnia tej części dorzecza jest najmniejsza i wynosi tylko 34,1 tys. $\mathrm{km}^{2}$ (23\% całego dorzecza) przy czym, w przeciwieństwie do dwu pozostałych, w całości należy do Polski. Zlewnia Dolnej Wisły jest prawie symetryczna, a rzeki, które ją drenują, mają charakter nizinny (np. Bzura, Skrwa), bardzo małe zasoby wodne i reżim śnieżny silnie lub średnio wykształcony albo pojezierny (np. Drwęca, Brda, Wda, Wieżyca), duże zasoby wodne, retencję i zasilanie podziemne oraz reżim śnieżny słabo lub średnio wykształcony. W najniżej położonym przekroju wodowskazowym Wisły w Tczewie średni wieloletni (1951-2016) przepływ Wisły wynosi: $\mathrm{SSQ}=1059 \mathrm{~m}^{3} \cdot \mathrm{s}^{-1}$, a zanotowane $\mathrm{w}$ tym samym okresie przepływy ekstremalne: $\mathrm{WWQ}=7750 \mathrm{~m}^{3} \cdot \mathrm{s}^{-1}$ (czerwiec 1962 r.), NNQ=264 $\mathrm{m}^{3} \cdot \mathrm{s}^{-1}$ (styczeń 1954 r.).

Ogromne zróżnicowanie fizycznogeograficzne (rzeźby, budowy geologicznej, wód podziemnych, klimatu, pokrycia terenu) dorzecza Wisły sprawia, że wzdłuż jej biegu zmieniają się nie tylko warunki formowania się odpływu w zlewniach, ale zmianie ulegają również warunki jego koncentracji, drenażu oraz sposoby transportu wody korytami. W efekcie reżim wodny Wisły zmienia się z jej biegiem, gdyż staje się wypadkową coraz większej liczby czynników i warunków występujących na coraz większym i coraz bardziej zróżnicowanym obszarze.

Hydrologom dobrze znany jest efekt hydrologiczny, jaki wywołuje wzrost powierzchni i zróżnicowania fizjograficznego zlewni. Ogólnie prowadzi to do jakościowych i ilościowych przemian reżimu odpływu oraz zmian charakteru rzeki i jej doliny. W miarę wzrostu powierzchni zlewni maleją zwykle średnie i maksymalne odpływy jednostkowe, a rosną minimalne. Zmniejsza się tym samym zmienność odpływu, a rośnie jego bezwładność. Zjawiska ekstremalne w zlewniach dużych (wezbrania, niżówki) rozwijają się i zanikają wolniej oraz trwają dłużej niż w małych. Jednocześnie nie są tak dotkliwe, zaś terminy ich ekstremów są coraz bardziej przesunięte w czasie w stosunku do czynnika sprawczego. Na to wszystko nakładają się efekty wywołane zmianami stacjonarnych i niestacjonarnych warunków formowania się odpływu. Na przykład Wisła i jej największe górne dopływy biorą początek w górach, gdzie infiltracja jest niewielka, a zima rozpoczyna się stosunkowo wcześnie i zanika późno, zaś opady letnie są wysokie i gwałtowne, a ewapotranspiracja jest stosunkowo mała. Inaczej jest w jej środkowym biegu, a jeszcze inaczej w dolnym. W miarę wzrostu powierzchni zlewni Wisły reżim tej rzeki winien być zatem coraz bardziej złożony, ale jednocześnie wpływ różnych, pojedynczych czynników i warunków fizycznogeograficznych występujących w jej dorzeczu coraz mniej widoczny, bowiem coraz mocniej zanurzony w specyficznym „szumie hydrologicznym”.

Jedną z prawidłowości decydujących o reżimie odpływu ze zlewni jest jego struktura sezonowa. Znajomość sezonowej zmienności odpływu rzecznego jest jednocześnie jedną z najbardziej podstawowych i najważniejszych informacji w praktyce hydrologicznej i gospodarce wodnej. Czasowy reżim odpływu rzecznego 
jest, z oczywistych powodów, funkcją sezonowego zróżnicowania wielkości i rodzaju opadów oraz natężenia parowania terenowego. Jednak obok czynników zewnętrznych (np. klimatycznych) ważną rolę odgrywa również cały kompleks zjawisk i procesów związanych z rzeką i jej zlewnią. Zlewnia i system rzeczny tworzą bowiem zespół filtrów, w których impulsy zewnętrzne (pogodowe, klimatyczne, antropogeniczne) są na tyle mocno transformowane, że przybierają często formę oraz rozkład czasowy bardzo różny od występującego na wejściu do systemu. W ten sposób działają np. różne rodzaje retencji, które zwiększają bezwładność systemu i spowalniają przemieszczający się w nim impuls opadowy (Jokiel, Tomalski 2017a).

Coroczna, mniej lub bardziej wyraźnie zarysowana, powtarzalność zjawisk hydrologicznych w Polsce jest oczywistą konsekwencją klimatycznie uwarunkowanych zmian pór roku, a co za tym idzie skutkiem powtarzających się, sezonowych zmian wielkości i rodzaju opadu atmosferycznego oraz sposobów jego redystrybucji. Wiosną spodziewamy się roztopów, opadów i wysokich przepływów w rzekach. Latem, pojawiają się zwykle niżówki, przerywane niekiedy dużymi wezbraniami opadowymi. Jesienią niżówki letnie wskutek niskich opadów lub ich braku mogą się pogłębić lub też, w efekcie wzrostu wilgotności i spadku parowania, całkowicie zaniknąć. Zimą przepływy rzek zwykle wzrastają, by przejść w roztopowe wezbrania śródzimowe, a później wiosenne. Wydaje się zatem, że cykl roczny jest zamknięty i wyraźnie zaznaczony, ale przecież jego powtarzalność w kolejnych latach jest względna. Zimy mogą być bowiem mroźne i długie albo łagodne i krótkie. Mogą być także śnieżne lub prawie bezśnieżne. Już tylko tych 6 ocen tej jednej pory roku daje możliwość utworzenia 12 „różnych zim” o cechach warunkujących bardzo zróżnicowany przebieg zjawisk hydrologicznych i to nie tylko w okresie tej pory roku, ale również w czasie wiosny, a nawet lata wskutek związanej z retencją bezwładności odpływu rzecznego.

Także w innych porach roku zaznacza się bardzo duża zmienność wieloletnia cech i charakterystyk klimatycznych. W efekcie, pory genetycznie różnych wezbrań i niżówek wędrują co roku dość swobodnie po osi czasu, przy czym wraz z położeniem na tej osi zmieniają się również ich parametry i geneza. Jeśli nałożymy na to dostrzegane już niekiedy hydrologiczne skutki trwałych bądź nietrwałych zmian klimatycznych i efekty antropopresji, zauważymy, że pojęcie „sezonowość odpływu” w coraz większym stopniu jest umowne i wymaga uściślenia, a nawet okresowego redefiniowania (Jokiel, Tomalski 2015).

\section{Materiał hydrometryczny i metody analiz}

Do analiz wykorzystano serie codziennych przepływów z 14 przekrojów wodowskazowych położonych wzdłuż biegu Wisły (tab. 1; ryc. 1). Serie pochodzą z wielolecia 1951-2016 (dla 2 przekrojów w Kępie Polskiej i Włocławku do analiz wykorzystano 
Tab. 1. Miary sezonowości przepływu Wisły w przekrojach jej biegu

Table 1. Flow seasonality characteristics in the selected Vistula water-gauge cross-sections

\begin{tabular}{|c|c|c|c|c|c|c|c|c|c|c|c|c|c|c|c|}
\hline $\begin{array}{l}\text { Lp } \\
\text { No. }\end{array}$ & $\begin{array}{c}\text { Przekrój } \\
\text { Water-gauge }\end{array}$ & $\begin{array}{c}\mathrm{A} \\
{\left[\mathrm{km}^{2}\right]}\end{array}$ & $\begin{array}{l}\mathrm{LW} \\
{[\mathrm{km}]}\end{array}$ & $\mathrm{IS}_{\mathrm{sr}}$ & IS $\mathrm{m}_{\text {maks }}$ & $\left|S_{\min }\right|$ & $\mathrm{PK}_{\mathrm{sr}}$ & $\mathrm{PK}_{\mathrm{poz} \dot{z}}$ & $\mathrm{PK}_{\mathrm{wcz}}$ & $\mathrm{TPO}_{\mathrm{sr}}$ & $\mathrm{TPO}_{\mathrm{poz}}$ & $\mathrm{TPO}_{\text {wcz }}$ & $\mathrm{GMO}_{\mathrm{Sr}}$ & $\mathrm{GMO}_{\text {maks }}$ & $G M 0_{\text {mi }}$ \\
\hline 1 & Skoczów & 297 & $-71,1$ & 30,7 & 60,2 & 3,7 & 175 & 259 & 97 & 183 & 260 & 126 & 13,7 & 22,5 & 9,8 \\
\hline 2 & Goczałkowice & 738 & $-37,8$ & 31,8 & 72,7 & 5,5 & 182 & 274 & 101 & 190 & 295 & 85 & 14,5 & 30,2 & 9,8 \\
\hline 3 & Nowy Biert & 1748 & $-3,6$ & 22,5 & 54,0 & 1,3 & 170 & 269 & 94 & 179 & 265 & 95 & 11,6 & 21,8 & 8,6 \\
\hline 4 & Jagodniki & 12058 & 153,1 & 22,4 & 45,4 & 4,2 & 178 & 270 & 93 & 179 & 259 & 124 & 10,8 & 17,3 & 8,6 \\
\hline 5 & Szczucin & 23901 & 194,1 & 24,7 & 46,9 & 4,4 & 184 & 268 & 99 & 183 & 259 & 128 & 10,8 & 15,9 & 9,0 \\
\hline 6 & Sandomierz & 31846 & 268,4 & 25,4 & 47,0 & 2,0 & 180 & 272 & 97 & 181 & 259 & 122 & 10,9 & 15,3 & 8,9 \\
\hline 7 & Zawichost & 50732 & 287,6 & 26,3 & 50,5 & 2,5 & 167 & 265 & 94 & 177 & 258 & 124 & 11,0 & 17,7 & 8,9 \\
\hline 8 & Annopol & 51518 & 298,4 & 25,8 & 48,5 & 2,6 & 169 & 273 & 94 & 177 & 257 & 121 & 10,9 & 18,3 & 8,8 \\
\hline 9 & Dęblin & 68234 & 393,0 & 24,7 & 48,6 & 4,5 & 164 & 267 & 93 & 176 & 259 & 125 & 10,6 & 18,0 & 8,6 \\
\hline 10 & $\begin{array}{c}\text { Warszawa } \\
\text { Nad. }\end{array}$ & 84540 & 504,1 & 23,7 & 48,1 & 7,2 & 167 & 274 & 95 & 175 & 259 & 126 & 10,4 & 19,2 & 8,5 \\
\hline 11 & Kępa Polska & 168956 & 606,5 & 23,0 & 38,1 & 7,4 & 153 & 249 & 94 & 169 & 243 & 127 & 10,0 & 17,0 & 8,7 \\
\hline 12 & Włocławek & 172389 & 679,4 & 24,0 & 41,0 & 9,9 & 153 & 251 & 92 & 168 & 242 & 124 & 10,2 & 16,6 & 8,6 \\
\hline 13 & Toruń & 181033 & 734,0 & 23,9 & 42,2 & 10,7 & 154 & 252 & 92 & 168 & 241 & 118 & 10,2 & 16,6 & 8,6 \\
\hline 14 & Tczew & 194376 & 908,6 & 23,4 & 40,2 & 8,0 & 156 & 254 & 93 & 169 & 241 & 114 & 10,1 & 16,5 & 8,7 \\
\hline
\end{tabular}

Objaśnienia: A, Lw - powierzchnia zlewni i kilometraż Wisły; IS - indeksy sezonowości (średni, maksymalny, minimalny); PK - pory koncentracji (średnia, najpóźniejsza, najwcześniejsza, por. tab. 2); TPO - terminy połowy odpływu (średni, najpóźniejszy, najwcześniejszy, por. tab. 2); GMO - wskaźniki sezonowości (średni, maksymalny, minimalny).

Explanations: A - area of the Vistula drainage basin, Lw - river mileage; IS - seasonality index (average, maximum, minimum); PK - period of seasonal concentration (average, latest, earliest, see tab. 2); TPO - half-flow date (average, latest, earliest, see tab. 2); GMO - concentration index (average, maximum, minimum).

serie nieco krótsze). Dane pochodzą z bazy IMGW-PIB. Na ich podstawie uzyskano niezbędne do analiz wybrane przepływy charakterystyczne, w tym macierze wartości średnich miesięcznych oraz krzywe sumowe odpływu.

Do oceny sezonowości przepływu Wisły w tych przekrojach i w skali ww. wieloleci wykorzystano 4 miary sezonowości. Dwie bezwzględne: wskaźnik pory koncentracji 
(PK) i termin połowy odpływu - TPO (Markham 1970; Jokiel, Bartnik 2005; McCabe, Clark 2005; Jokiel 2009) oraz dwie miary względne: indeks sezonowości odpływu (IS) i wskaźnik koncentracji odpływu - GMO (Oliver 1980; Soja 2002; Jokiel, Tomalski 2017b). Z badań przeprowadzonych przez autorów (2017b) wynika, że wskaźnik koncentracji odpływu GMO (Olivera) odzwierciadla podobne aspekty sezonowości co indeks sezonowości IS (Markhama). Uwzględniając ten fakt, w wyżej cytowanym opracowaniu zaproponowaliśmy, by w przypadku GMO używać terminu: wskaঞnik sezonowości odptywu, nie zaś wskaঞnik koncentracji odptywu (jak zaproponował Soja, 2002), tę drugą nazwę: wskaznik pory koncentracji (PK), rezerwując dla miary zdefiniowanej przez Markhama (1970).

Przegląd innych metod i wskaźników służących ocenie sezonowości odpływu zawierają prace: Bartnika i Jokiela (2005), Wrzesińskiego (2013) oraz Tomalskiego i Tomaszewskiego (2015). Pierwszą i trzecią z wymienionych miar sezonowości zaproponował Markham dla wartości dobowych (1970). Dla przepływów średnich miesięcznych dostosowali je Jokiel i Bartnik (2001).

Rozważmy szereg średnich przepływów miesięcznych, którego każdy element utożsamiany jest $\mathrm{z}$ wektorem $\overrightarrow{\mathrm{r}}(1,2,3, \ldots 12)$ o długości proporcjonalnej do jego wartości i kierunkiem wyrażonym kątem $\alpha_{i}$. Kąt ten jest proporcjonalny do odległości czasowej między dniem będącym środkiem danego miesiąca i początkiem roku (tu hydrologicznego). Wypadkową 12 wyznaczonych w ten sposób wektorów $\vec{r}_{i}$ jest wektor $\vec{R}$ o module $|\vec{R}|$ i kierunku $\omega$. Jeżeli długość wektora wypadkowego $|\vec{R}|$ podzielimy przez sumę długości wektorów cząstkowych $\left|\vec{r}_{i}\right|$, otrzymamy indeks sezonowości przepływu $\left(I S_{j}\right)$, charakterystyczny dla roku $j$.

$$
I S_{j}=\frac{\left|\vec{R}_{j}\right|}{\sum\left|\vec{r}_{i}\right|} \cdot 100 \%
$$

Wskaźnik ten jest względny i może zawierać się w przedziale od 0 do 100\%, przy czym wartości najmniejsze mogą dotyczyć dwu sytuacji: gdy odpływ rozłożony jest równomiernie w ciągu roku (długość wszystkich wektorów jest taka sama) - brak sezonowości odpływu, lub gdy układ wektorów cząstkowych tworzy dwie przeciwstawne wypadkowe (np. odpływ koncentruje się 1 listopada i 1 maja). Jeśli IS jest bliski 100\%, przepływy miesięczne w danym roku cechują się skrajnie dużą sezonowością, np. rzeka jest okresowa.

Drugą z charakterystyk zaproponowanych przez Markhama do badania sezonowości jest wskaźnik pory koncentracji przepływu (PK). Bazuje ona na tych samych założeniach, co indeks sezonowości, ale jest wartością bezwzględną. Miarą jest tu kąt nachylenia wektora $\vec{R}$. Wskazuje on (w mierze kątowej) ważoną porę koncentrowania się przepływów w roku wyrażoną wartością $\omega$. W analizach hydrologicznych zamiast $\omega$ wygodniej jest używać konkretnej daty. Można ją uzyskać 
z relacji $360^{\circ}=365(366)$ dni. Dla przepływów średnich miesięcznych kąt $\omega$ oblicza się wzorem:

$$
w=\operatorname{arctg}\left(\frac{\sum_{i=1}^{12}\left|\vec{r}_{i}\right| \cos \alpha_{i}}{\sum_{i=1}^{12}\left|\vec{r}_{i}\right| \sin \alpha_{i}}\right)
$$

Kolejną bezwzględną miarę sezonowości, a ściśle mówiąc „rozmieszczenia” odpływu w ciągu roku, po raz pierwszy zdefiniowano i zastosowano w opracowaniu Bartnika i Jokiela (2005). Jest nią termin połowy odpływu (TPO). Jest ona łatwa w konstrukcji i interpretacji. Powstaje w wyniku analizy względnej krzywej sumowej (kumulowanej) odpływu rocznego i wskazuje dzień w roku, w którym kumulowane odpływy (od początku roku hydrologicznego) osiągną 50\% sumy rocznej (Jokiel 2016). W tym samym roku, podobną miarę nazwaną CMD (central of mass data), zaproponowali McCabe i Clark (2005). Dla roku j, TPO ustalimy wg formuły:

$$
T P O_{j}=\left\{i: V_{i}=V_{365(12)} / 2\right\}
$$

gdzie:

$V_{i}$ - suma odpływu $\left[\mathrm{m}^{3}\right]$; liczona od 1 listopada (początek roku hydrologicznego), $V_{365(12)}$ - roczna suma odpływu $\left[\mathrm{m}^{3}\right]$,

$T P O_{j}-$ dzień (miesiąc) osiągnięcia $V_{i}=V_{365(12)} / 2$.

Wynik uzyskiwany przy obliczaniu TPO i PK to dzień od początku roku hydrologicznego. W celu łatwiejszej analizy zamieszczono w tabeli 2. uproszczony kalendarzyk terminów i dat.

Tab. 2. Kalendarzyk terminów i dat PK i TPO

Table 2. PK and TPO days of year and dates calendar

\begin{tabular}{|c|c|c|c|c|c|c|c|c|c|c|c|c|c|}
\hline $\begin{array}{c}\text { Dzień } \\
\text { Day }\end{array}$ & 93 & 107 & 122 & 136 & 152 & 166 & 182 & 196 & 213 & 228 & 242 & 257 & 275 \\
\hline $\begin{array}{c}\text { Data } \\
\text { Date }\end{array}$ & $1 \mathrm{II}$ & $15 \mathrm{II}$ & $1 \mathrm{III}$ & $15 \mathrm{III}$ & $1 \mathrm{IV}$ & $15 \mathrm{IV}$ & $1 \mathrm{~V}$ & $15 \mathrm{~V}$ & $1 \mathrm{VI}$ & $15 \mathrm{VI}$ & $1 \mathrm{VII}$ & $15 \mathrm{VII}$ & $1 \mathrm{VIII}$ \\
\hline
\end{tabular}

Do konstrukcji wskaźnika sezonowości odpływu GMO, przywołany już wyżej Oliver, wykorzystał opracowaną wcześniej miarę służącą badaniu rozmieszczenia opadów w ciągu roku (tzw. reżimu opadowego). Wskaźnik GMO jest względny i bazuje na odpływach średnich miesięcznych, a zatem na interwałach czasowych, które są również podstawą obliczeń dwu wymienionych wcześniej miar Markhama. Formuła obliczeniowa wskaźnika sezonowości odpływu dla roku $j$ wygląda następująco: 


$$
G M O_{j}=\frac{\sum_{i=1}^{12}\left(S Q M_{i}\right)^{2}}{\left(\sum_{i=1}^{12} S Q M_{i}\right)^{2}} \cdot 100
$$

gdzie:

$G M O_{j}$ - wskaźnik sezonowości odpływu w roku j, $S Q M_{i}$ - Średni miesięczny przepływ w miesiącu $i$.

Ze sposobu konstrukcji wskaźnika GMO wynika, że przy braku sezonowości odpływu (średni przepływ we wszystkich miesiącach roku hydrologicznego jest jednakowy), jego wartość wynosi 8,3. Przy wystąpieniu odpływu tylko w jednym miesiącu (maksymalna sezonowość), wskaźnik jest równy 100.

Należy podkreślić, iż wszystkie wskazane wyżej charakterystyki mają też pewne, właściwe sobie, niedogodności. Definiując je, przyjmujemy między innymi założenie, iż rok hydrologiczny jest „zamkniętą” jednostką czasową, w której odpływy (dobowe, miesięczne) są niezależne od występujących wcześniej i nie będą miały wpływu na późniejsze. W kontekście dużej inercji odpływu, powodowanej między innymi retencją, założenie to nie jest prawdziwe i należy stale o tym pamiętać (Jokiel 2009).

Wybrane i zdefiniowane wyżej miary posłużyły do prześledzenia zmian sezonowości przepływu Wisły wzdłuż jej biegu, zarówno w warunkach przeciętnych, jak i ekstremalnych (lata powodziowe i susz hydrologicznych), a dla 3 wybranych przekrojów zamykających kluczowe odcinki rzeki (Zawichost, Warszawa i Tczew) przeprowadzono również analizę ich zmienności w skali wielolecia oraz wzajemnych powiązań.

\section{Zmiany sezonowości przepływu wzdłuż biegu Wisły}

Średnia sezonowość przepływu Wisły wyrażona IS i GMO jest największa w dwu górnych przekrojach (Skoczów i Goczałkowice), w trzech kolejnych maleje (Nowy Bieruń, Jagodniki, Szczucin), by znowu wzrosnąć w Sandomierzu, Zawichoście i Annopolu. Prawidłowość ta dotyczy również indeksów i wskaźników ekstremalnych (ryc. 2A i G). Poniżej Annopola sezonowość ponownie maleje, by w przekrojach dolnej Wisły (od Kępy Polskiej do Tczewa) ustabilizować się na podobnym poziomie. Średnie indeksy IS zawierają się w przedziale od 31,8\% (Goczałkowice) do 22,4\% (Jagodniki), przy czym warto podkreślić, że największe i najmniejsze średnie IS uzyskano dla przekrojów Górnej Wisły, co oznacza, że sezonowość odpływu jest najbardziej zmienna w górnym biegu tej rzeki. Także wskaźnik GMO potwierdza, że największą sezonowość mają przepływy w przekrojach Małej Wisły (14,5 dla Goczałkowic), jednak najmniejszą pokazuje w przekrojach Wisły Dolnej (Kępa Polska 

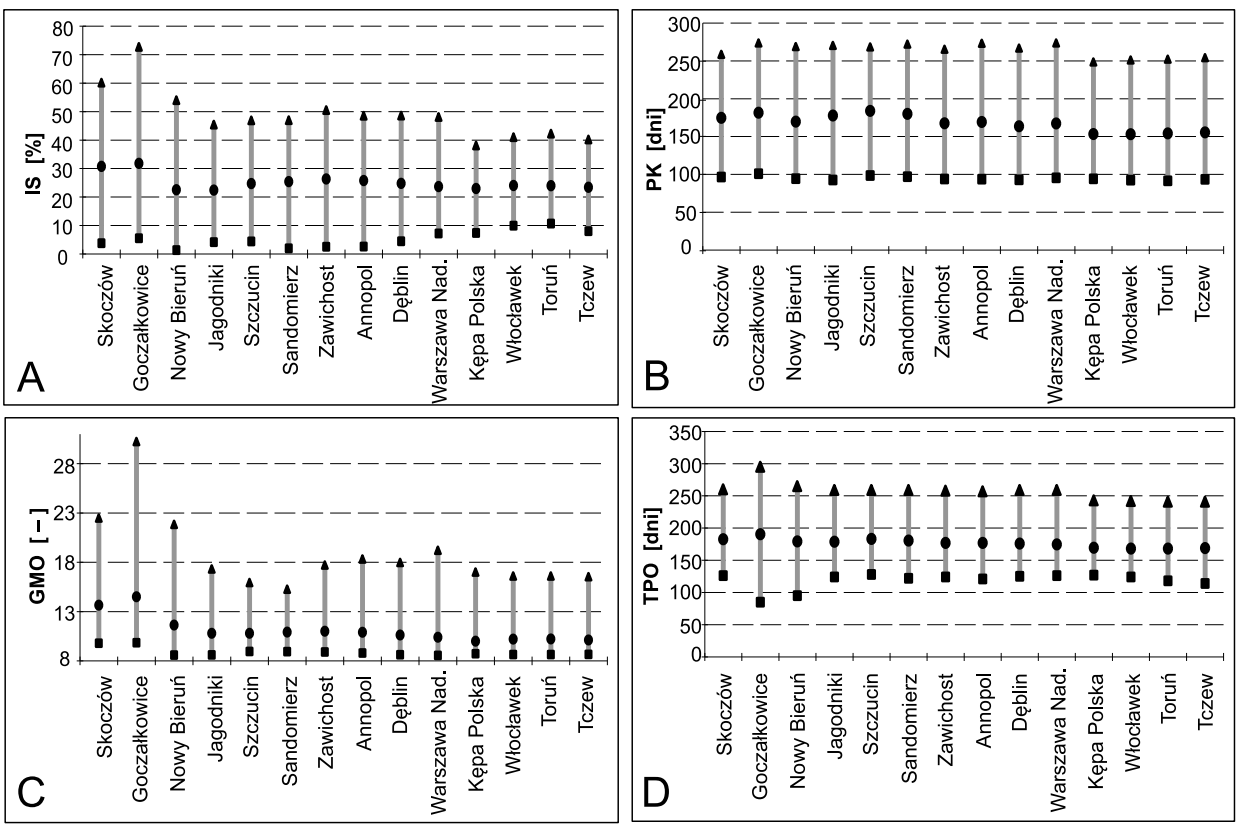

Ryc. 2. Średnie i ekstremalne miary sezonowości przepływu Wisły w wybranych przekrojach wodowskazowych

Fig. 2. Average and extreme seasonality characteristics of the Vistula river flow in the selected water-gauges

Objaśnienia: IS - indeks sezonowości, GMO - wskaźnik sezonowości, PK - termin pory koncentracji, TPO - termin połowy odpływu.

Explanations: IS - seasonality index, GMO - concentration index, $\mathrm{PK}$ - period of seasonal concentration, TPO - half-flow date.

i Tczew - 10,0). Warto również zwrócić uwagę, że w przekrojach Wisły Środkowej (od Zawichostu do Warszawy), wskaźniki GMO cechuje relatywnie szeroki przedział zmienności (w niektórych latach sezonowość może być stosunkowo duża, w innych bardzo mała). Co ciekawe, w przekroju Sandomierz wieloletnie zróżnicowanie sezonowości, mierzone GMO, jest najmniejsze wśród odnotowanych (ryc. 2C, tab.1).

Przeciętne wskaźniki pory koncentracji PK zawierają się w przedziale od 184. dnia w Szczucinie do 153. dnia we Włocławku i Kępie Polskiej (tab.1). Różnica wynosi ok. 1 miesiąca. Od Skoczowa do Sandomierza średnie PK są relatywnie późne (powyżej 170. dnia roku hydrologicznego), od Zawichostu do Warszawy - przeciętne (od 160. do 170. dnia), a poniżej Warszawy stosunkowo wczesne (poniżej 160. dnia). Warto zauważyć, że ekstremalnie wczesne PK niemal we wszystkich 
przekrojach mieszczą się w wąskim przedziale 90 do 100 dni, zaś ekstremalnie późne od 250 do 280. Przeciętnie, połowa rocznych zasobów wodnych odpływa najwcześniej przez przekrój we Włocławku (168. dzień roku), a najpóźniej przez Goczałkowice. Między Skoczowem a Sandomierzem połowa zasobów odpływa na przełomie kwietnia i maja, między Zawichostem i Warszawą w trzeciej dekadzie kwietnia, a poniżej Warszawy w drugiej dekadzie. Duże zróżnicowanie wykazują ekstremalne TPO, przy czym w Goczałkowicach zaznacza się wyraźnie wpływ zbiornika wodnego. W niektórych latach (wilgotnych i powodziowych) opóźnia on bardzo TPO (295. dzień), a w latach suchych przyspiesza - wskutek szybkiego wyczerpywania się zgromadzonych w zbiorniku zasobów (85. dzień). Pomijając ten przekrój, ekstremalnie późne TPO od Skoczowa do Warszawy są mało zróżnicowane (ok. 257.-265. dzień). Również poniżej zróżnicowanie nie jest duże, choć TPO wypadają wyraźnie wcześniej (240.-243. dzień).

Zmiany wszystkich czterech miar średniej sezonowości przepływu z biegiem Wisły i w miarę przyrostu powierzchni jej zlewni dobrze ilustrują diagramy zamieszczone na ryc. 3. Prawidłowości wykazane wcześniej są tu wyraźnie widoczne. Załamania krzywej IS znakomicie korespondują ze zmianą reżimu Wisły wskutek dopływu Dunajca (Szczucin), Sanu (Zawichost) i oddziaływania Zbiornika Włocławskiego. Odmienna struktura sezonowa odpływu ze zlewni dwu wymienionych wyżej dopływów, wpływa zatem na skokowe zmiany sezonowości odpływu Wisły, znacząco podnosząc lub hamując spadek sezonowości odpływu w dolnym biegu rzeki. Co ciekawe, podobnie oddziałuje Zbiornik Włocławski (por. wpływ Zbiornika Goczałkowickiego). Prawidłowości tej nie dostrzeżemy jednak w przypadku Narwi (Kępa Polska). Ogromny przyrost przepływu i powierzchni zlewni Wisły po przyjęciu Narwi i Bugu nie skutkuje wzrostem sezonowości jej przepływu. Wprost przeciwnie, IS Wisły poniżej ujścia Narwi maleje, co dowodzi, że sezonowa struktura odpływu Narwi i Bugu jest podobna do występującej w Wiśle w przekrojach położonych bezpośrednio powyżej ich ujścia. Prawidłowości takie, choć mniej wyraźnie, są również widoczne, jeśli przeanalizujemy zmiany GMO.

Wskaźniki pory koncentracji (PK) i terminy połowy odpływu (TPO) Wisły wyraźnie maleją z jej biegiem. Tendencje ich zmian w funkcji kilometrażu (ryc. 3A i C) i powierzchni zlewni (ryc. 3B i D) da się nawet opisać statystycznie istotnymi ( $\alpha=1 \%$; test F-Snedecora) równaniami regresji. Błędy statystyczne równań są oczywiście duże, ale współczynniki determinacji $\left(R^{2}\right)$ we wszystkich przypadkach wskazują na dobry lub bardzo dobry stopień wyjaśniania. Należy podkreślić, że lepsze dopasowania równań uzyskano dla TPO i związków z powierzchnią zlewni (A) niż w odniesieniu do PK i powiązań z kilometrażem Wisły (LW). 


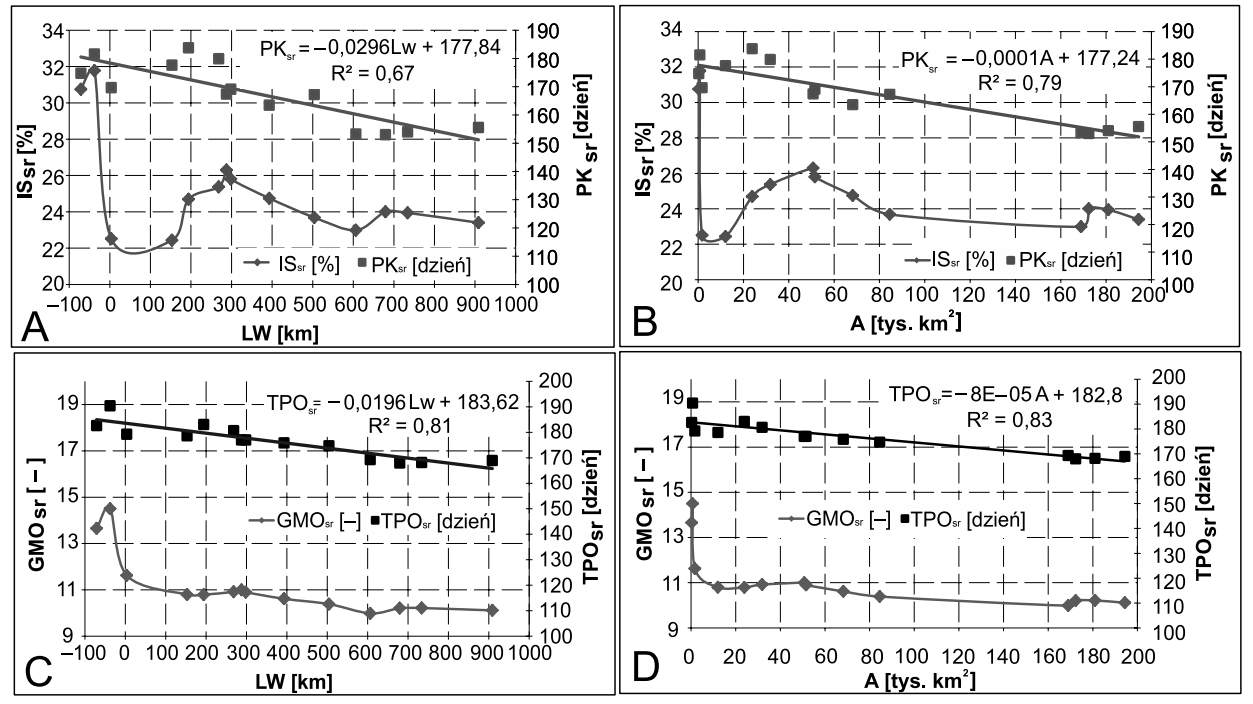

Ryc. 3. Zmiany sezonowości przepływu w przekrojach Wisły w funkcji kilometrażu rzeki i powierzchni jej zlewni

Fig. 3. Flow seasonality changes in the Vistula cross-sections in the function of the river mileage and the area of the drainage basin

Objaśnienia: IS - indeks sezonowości, GMO - wskaźnik sezonowości, PK - termin pory koncentracji, TPO - termin połowy odpływu, Lw - kilometraż Wisły, A - powierzchnia zlewni Wisły.

Explanations: IS - seasonality index, GMO - concentration index, PK - period of seasonal concentration, TPO - half-flow date, Lw - river mileage, A - area of drainage basin.

\section{Sezonowość przepływu Wisły w latach powodzi i susz hydrologicznych}

Do zbadania zmian sezonowości przepływu Wisły w latach powodziowych wybrano 5 lat z badanego wielolecia, w których w dolinie Wisły lub w dolinach wielu jej dopływów wystąpiły duże wezbrania i towarzyszące im powodzie. Analizie poddano cztery ww. miary sezonowości obliczone dla 12 przekrojów w latach: 1960 (duża powódź wywołana lipcowymi i sierpniowymi opadami, głównie w dorzeczu Środkowej i Dolnej Wisły), 1962 (duża powódź wywołana opadami czerwcowymi, głównie w zlewniach rzek nizinnych Dolnej, a w mniejszym stopniu Środkowej Wisły), 1970 (gwałtowna powódź lipcowa wywołana opadami w obrębie karpackiej części dorzecza Górnej Wisły), 2001 (ogromna letnia powódź opadowa na przełomie 


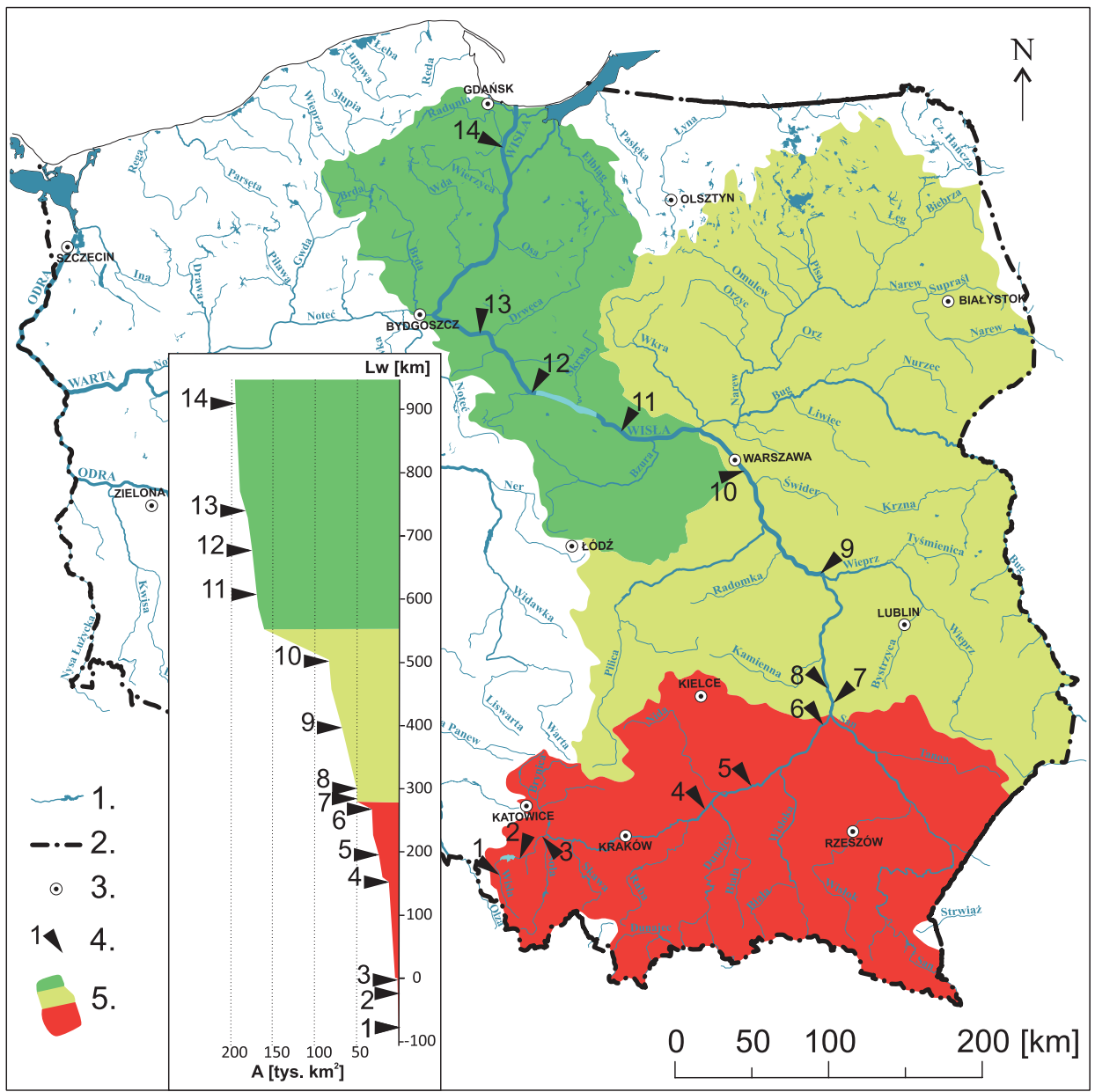

Ryc.1. Wybrane przekroje wodowskazowe wzdłuż biegu Wisły

Fig. 1. Selected water-gauge cross-sections along the Vistula river

Objaśnienia: 1 - rzeki, jeziora, 2 - granice państwa, 3 - miasta, 4 - przekroje wodowskazowe (numeracja zgodna z tab.1), 5 - dorzecze Wisły; kolorami oznaczono zlewnię Wisły Górnej (czerwony), Środkowej (żółty) i Dolnej (zielony), Lw - kilometraż Wisły, A - powierzchnia zlewni Wisły.

Explanations: 1 - rivers, reservoirs, 2 - country boundary, 3 - cities, 4 - water-gauges (numbers according to tab. 1), 5 - Vistula river drainage basin; colours show the Upper Vistula drainage basin (red), the Middle Vistula drainage basin (yellow), and the Lower Vistula drainage basin (green), Lw - river mileage, A - area of the Vistula drainage basin. 

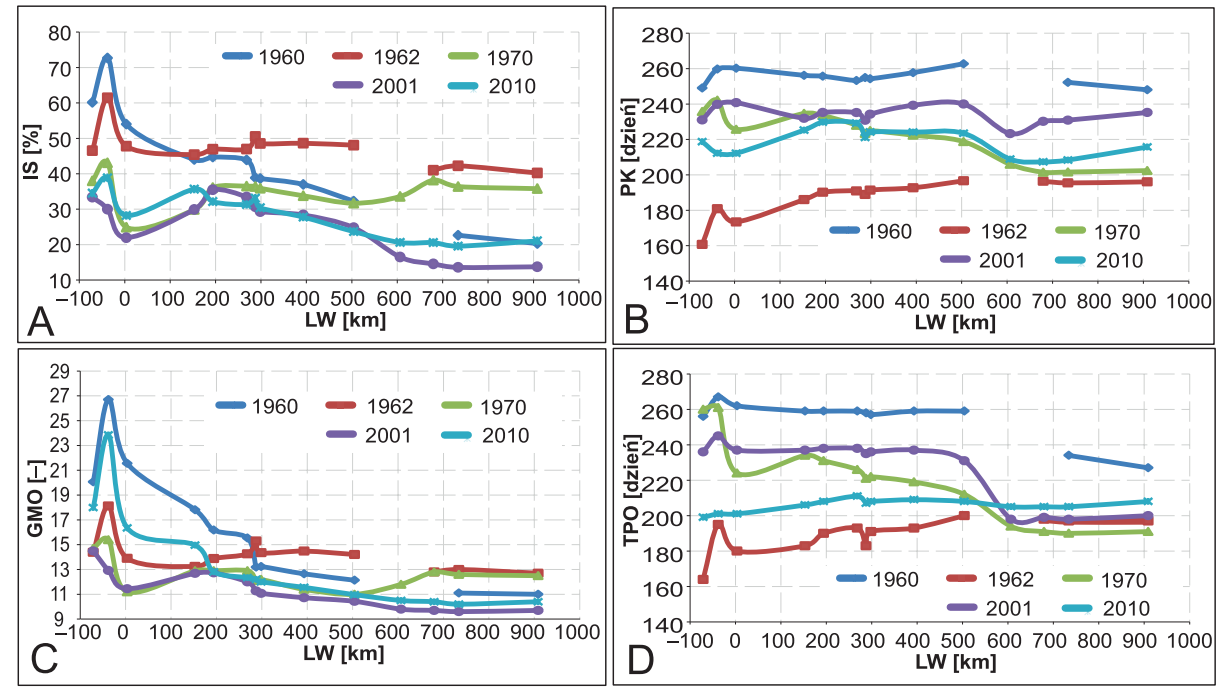

$\mathrm{B}$ LW [km]

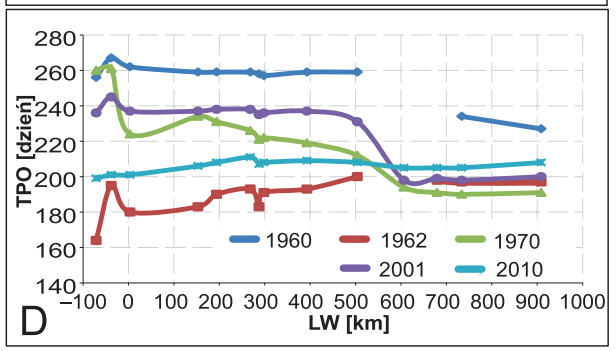

Ryc. 4. Zmiany sezonowości z biegiem Wisły w latach powodziowych

Fig. 4. Seasonality changes along the Vistula River in flood years

Objaśnienia: IS - indeks sezonowości, GMO - wskaźnik sezonowości, PK - termin pory koncentracji, TPO - termin połowy odpływu, LW - kilometraż Wisły.

Explanations: IS - seasonality index, GMO - concentration index, PK - period of seasonal concentration, TPO - half-flow date, $\mathrm{Lw}$ - river mileage.
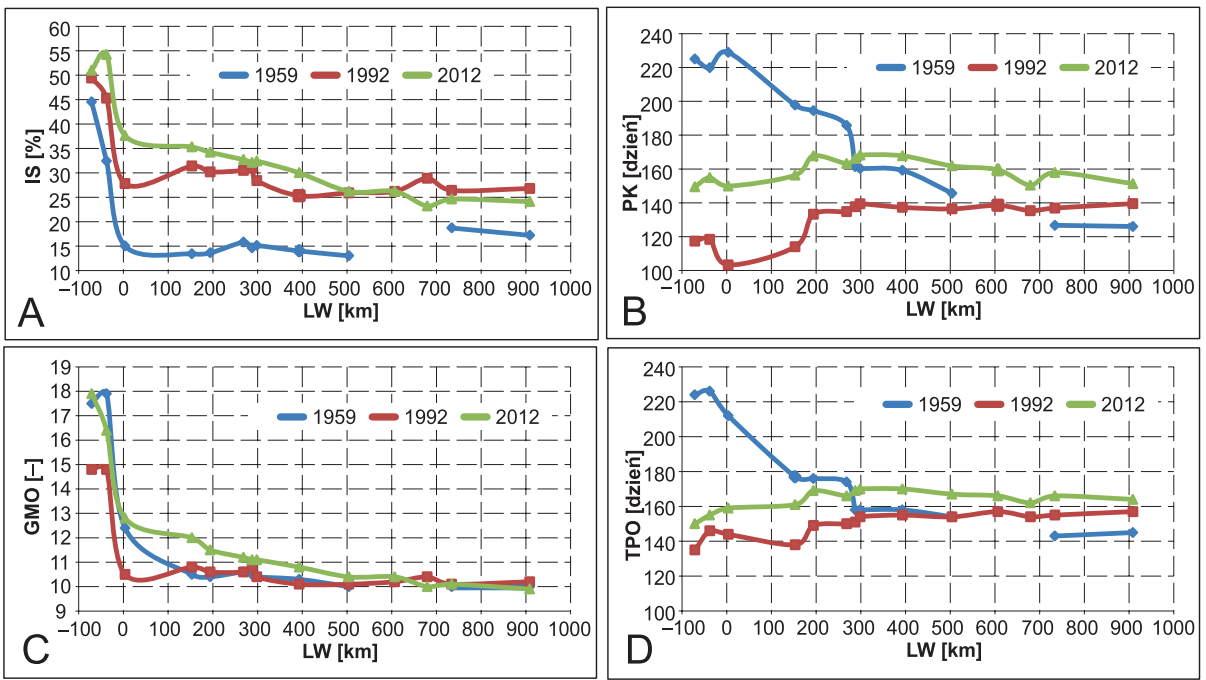

Ryc. 5. Zmiany sezonowości z biegiem Wisły w latach suchych

Fig. 5. Seasonality changes along the Vistula River in dry years

Objaśnienia: IS - indeks sezonowości, GMO - wskaźnik sezonowości, PK - termin pory koncentracji, TPO - termin połowy odpływu, LW - kilometraż Wisły.

Explanations: IS - seasonality index, GMO - concentration index, PK - period of seasonal concentration, TPO - half-flow date, $\mathrm{Lw}$ - river mileage. 
lipca i sierpnia, głównie w dorzeczu Środkowej i Dolnej Wisły), 2010 (wielka powódź w drugiej dekadzie maja i w połowie czerwca, w obrębie Górnej i Środkowej Wisły z charakterystyczną podwójną falą wezbraniową). W dwu przypadkach (przekroje: Kępa Polska i Włocławek) obliczeń nie wykonano dla lat 1960 i 1962 z uwagi na fakt, iż obserwacje na tych wodowskazach rozpoczęto dopiero w latach 1961 i 1969 (ryc. 4).

Indeksy sezonowości (IS) w pięciu latach powodziowych były w badanym wieloleciu dość zróżnicowane, przy czym największą sezonowością przepływu cechował się rok 1962 (w prawie wszystkich przekrojach IS $=40-50 \%$ ), a najmniejszą lata 2001 i 2010 (IS=15-35\%). W 1960 r. sezonowość przepływu Wisły była także bardzo wysoka, ale tylko w górnych przekrojach, natomiast w biegu środkowym i dolnym szybko malała w miarę przyrostu dorzecza - od 60\% do 25\% (ryc. 4A). W 1970 r. indeksy sezonowości były we wszystkich przekrojach bliskie przeciętnej i jednocześnie mało zróżnicowane z biegiem Wisły. Nieco inny jest obraz zmian sezonowości przepływu Wisły uzyskany za pomocą wskaźnika GMO (ryc. 4C). W latach 1960 i 2010 wskaźniki te były bardzo wysokie w górnym biegu (16-27\%), co wskazuje na dużą sezonowość przepływu, ale bardzo szybko malały wraz z przyrostem dorzecza Wisły (do ok. 11\%). Natomiast w trzech pozostałych latach powodziowych, GMO były relatywnie niskie (10-15\%), co dowodzi małej sezonowości przepływu, oraz mało zróżnicowane z biegiem rzeki, co wskazuje z kolei na względne podobieństwo rocznego rozkładu odpływu w całym dorzeczu. Ale nawet i w tych latach spadek sezonowości przepływu z biegiem Wisły był dość wyraźny.

Zupełnie innym zróżnicowaniem w poszczególnych latach cechują się terminy pory koncentracji i terminy połowy odpływu (ryc. 4B i D). Widoczna jest wyraźnie korelacja między obiema miarami (zagadnienie to omówimy niżej) oraz stosunkowo małe zróżnicowanie obu miar z biegiem rzeki, przy jednocześnie dużych różnicach w odniesieniu do poszczególnych lat. Najpóźniejsze PK i TPO wystąpiły w roku 1960 (odpowiednio: 250-260 i 230-270), a najwcześniejsze w 1962 r. (160-195). Różnica średnich wynosiła w obu przypadkach ok. 60 dni. Jest ciekawe, że zarówno PK, jak i TPO w 1962 r. wzrastały z biegiem rzeki, a w 1970 r. wyraźnie malały. Natomiast w powodziowych latach 2001 i 2010 wartości PK i TPO były bliskie przeciętnym, przy czym w tym ostatnim roku ich zróżnicowanie w obrębie całej Wisły było prawie niezauważalne. Warto jednak podkreślić, że terminy koncentracji (PK) i połowy odpływu (TPO) były w latach powodziowych bardzo zróżnicowane, przy czym różnice między poszczególnymi latami były większe niż różnice występujące między wartościami uzyskanymi dla poszczególnych przekrojów w danym roku.

Do oceny zmian sezonowości przepływu Wisły w latach suchych wybrano 3 lata cechujące się długimi, głębokimi i licznymi niżówkami w tej rzece. W ocenie Kępińskiej-Kasprzak (2013) były to lata 1959 i 1992, w których, odpowiednio w 54 i 56 przekrojach wodowskazowych Polski (75 i 78\% badanych) zanotowano zjawisko suszy hydrologicznej. Dodano do tego zbioru rok 2012, który zapisał się szczególnie 
niskimi przepływami Wisły w jej środkowym biegu i dużą liczbą niżówek w rzekach dorzecza Górnej Wisły.

Wskaźniki sezonowości GMO we wszystkich trzech latach były podobne i w podobnym tempie malały z biegiem Wisły. W trzech pierwszych przekrojach sezonowość była stosunkowo duża i dość zróżnicowana (10-18\%), by poniżej zmaleć do 10-12\% (ryc. 5A i C). Nieco inaczej zmieniał się indeks IS. W latach 1992 i 2012 wartości IS i ich zmiany z biegiem rzeki były podobne (od ok.50\% w górnym biegu do ok. 25\% w dolnym). Natomiast w roku 1959 sezonowość przepływu była wyraźnie mniejsza (od 45 i 32\% w dwu przekrojach górnych do poniżej 15\% w większości przekrojów środkowej Wisły, przy czym stosunkowo dużą sezonowością przepływu (ok. 17\%) cechowała się Dolna Wisła (17-20\%).

Różnice między latami 1992 i 2012 oraz rokiem 1959 jeszcze wyraźniej widać, gdy przeanalizujemy zmiany PK i TPO (ryc. 5B i D). W dwu pierwszych latach najpóźniejsze terminy koncentracji i połowy odpływu wystąpiły w przekrojach Środkowej Wisły (odpowiednio: 170. dzień roku - PK i 140.-160. dzień roku - TPO), zaś najwcześniejsze w przekrojach Małej Wisły (odpowiednio: 150.-160. i 100.-140. dzień roku). Choć oba terminy były w roku 2012 nieco późniejsze niż w 1992, to ich stabilność z biegiem Wisły w obu latach wskazuje na wyraźne podobieństwo sezonowej struktury odpływu w poszczególnych zlewniach dorzecza Wisły i prosty, śnieżny reżim odpływu w całym dorzeczu. Inaczej w roku 1959, do przekroju w Sandomierzu PK i TPO były stosunkowo późne (majowo-czerwcowe), głównie z uwagi na istotny wpływ letnich opadów w dorzeczu Górnej Wisły. Tym samym reżim w dorzeczu Górnej Wisły miał w tym roku charakter złożony, śnieżno-deszczowy, a w środkowym i dolnym - śnieżny (PK i TPO mniejsze od 160 - pora koncentracji i połowa odpływu wcześniej niż 15 kwietnia).

\section{Wieloletnie zmiany i oscylacje sezonowości przepływu w wybranych przekrojach Wisły}

Do analizy wybrano 3 przekroje zamykające górną, środkową i dolną część dorzecza Wisły, dla których istnieją pełne serie obserwacyjne z lat 1951-2016: Zawichost, Warszawa Nadwilanówka i Tczew. Ten drugi warunek spowodował, że uwzględniono przekrój w Warszawie zamiast przekroju w Kępie Polskiej. Już pobieżna analiza diagramów prezentowanych na ryc. 6 dowodzi, że:

- występuje duża zbieżność zmian indeksów i wskaźników sezonowości w poszczególnych przekrojach, przy czym największe liczbowo wartości i największa ich dynamika dotyczy przekroju Zawichost, a najmniejsza - przekroju Tczew;

- w latach 1951-1975 indeksy IS systematycznie malały (sezonowość przepływu we wszystkich przekrojach zmniejszała się), zaś wskaźniki GMO cechowały się 

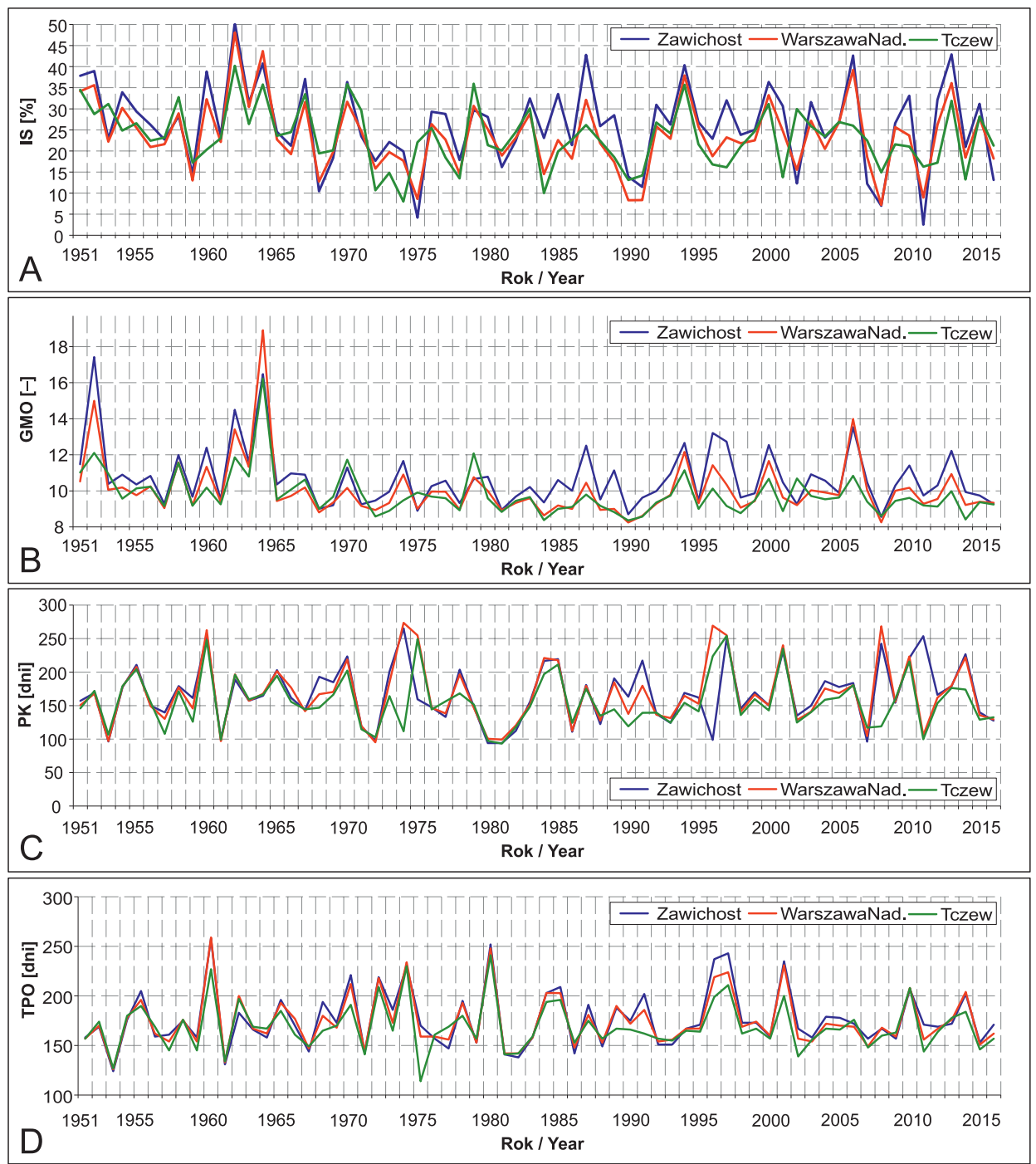

Ryc. 6. Dynamika zmian sezonowości przepływu Wisły w wybranych przekrojach Fig. 6. Dynamics of the Vistula flow seasonality changes in the selected cross-sections Objaśnienia: IS - indeks sezonowości, GMO - wskaźnik sezonowości, PK - termin pory koncentracji, TPO - termin połowy odpływu.

Explanations: IS - seasonality index, GMO - concentration index, PK - period of seasonal concentration, TPO - half-flow date. 


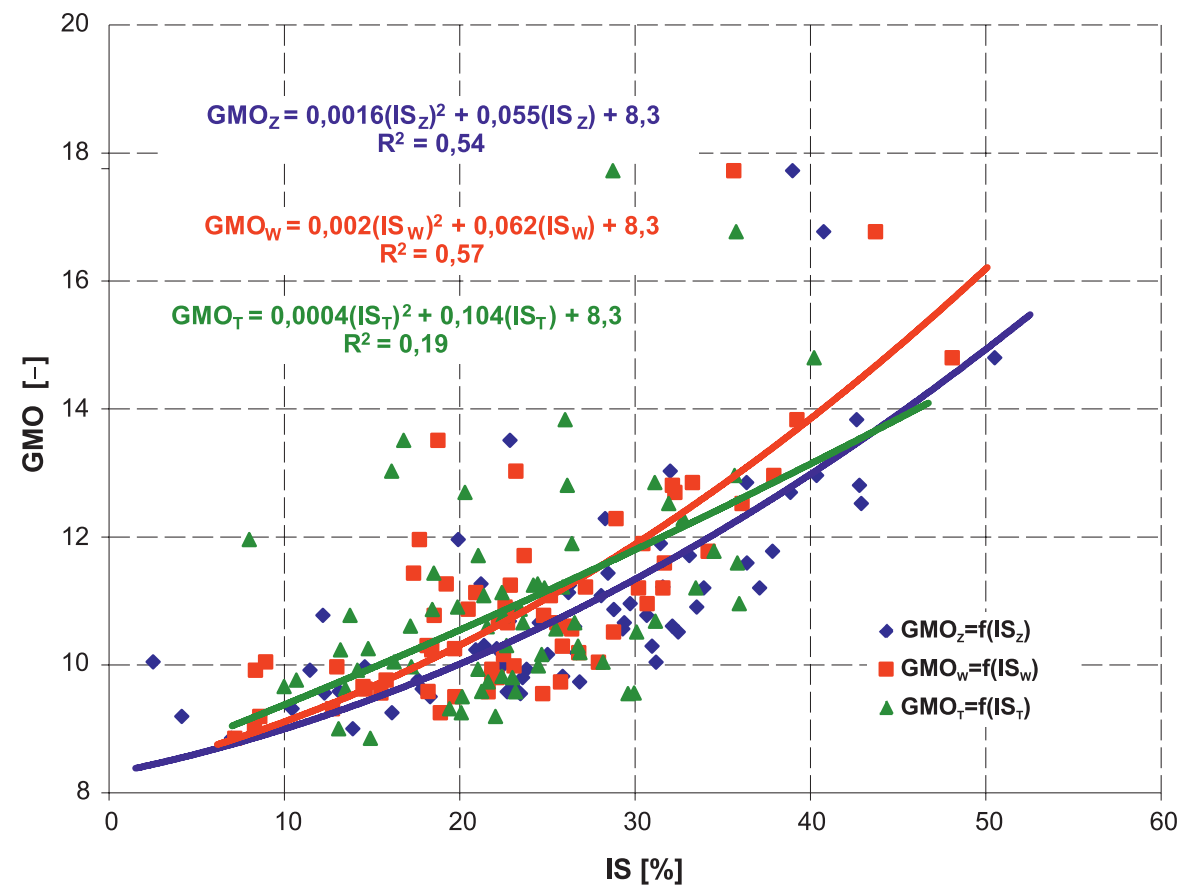

Ryc. 7. Związki między miarami sezonowości uzyskanymi dla przekrojów: Zawichost, Warszawa Nadwilanówka i Tczew

Fig. 7. Relations between the seasonality characteristics calculated for the following crosssections: Zawichost, Warszawa Nadwilanówka and Tczew

Objaśnienia: IS - indeks sezonowości, GMO - wskaźnik sezonowości (kolory linii i punków oznaczają przekroje: niebieski - Zawichost, czerwony - Warszawa Nadwilanówka, zielony - Tczew).

Explanations: IS - seasonality index, GMO - concentration index colours of lines and dots refer to the cross-sections: blue - Zawichost, red - Warszawa Nadwilanówka, green - Tczew). 
wówczas dużą zmiennością związaną z występowaniem lat o bardzo dużej sezonowości przepływu (1952, 1962, 1964); w późniejszych latach (IS po 1975 r., a GMO po roku 1970) sezonowość nieco zmalała, a zmiany miały charakter losowych oscylacji wokół wartości średniej (ryc. 6A i B);

- szeregi czasowe IS i GMO wszystkich trzech przekrojów cechują się zmiennością o charakterze losowych fluktuacji; sezonowość przepływu Wisły nie wykazywała zatem w tym okresie żadnej trwałej i statystycznie istotnej tendencji (ryc. 6A i B); - czasowa zbieżność zmian PK i TPO uzyskanych dla trzech przekrojów wydaje się jeszcze wyraźniejsza, choć w przypadku pory koncentracji pojawiają się lata wyraźnie odstające od tej reguły, np.: 1975, 1996, 2011 (w przekroju Zawichost pora koncentracji wyraźnie odbiegała od wartości uzyskanych dla dwu niżej położonych przekrojów; ryc. 6C i D).

Dowodem wyraźnej zbieżności zmian są wysokie i statystycznie istotne ( $\alpha=1 \%$; test Snedecora) współczynniki korelacji obliczone dla poszczególnych miar i przekrojów - tab. 3. Największa zbieżność zmian w wieloleciu występuje w odniesieniu do TPO i przekrojów Warszawa Nadwilanówka i Tczew, a najmniejsza w przypadku PK obliczonych dla Zawichostu i Tczewa. Ogólnie największą zbieżność zmian wykazuje TPO i miary obliczone dla przekrojów w Zawichoście i Warszawie.

Biorąc pod uwagę fakt, że pary miar IS i GMO oraz PK i TPO ilustrują podobny aspekt sezonowości przepływu rzeki (Jokiel, Tomalski 2017b), zidentyfikowano również równania ich związku. Z uwagi na wspomniane wcześniej anomalie związków między PK i TPO, uzyskane równania regresji PK=f(TPO) są słabo uwarunkowane, mają ogromne błędy regresji i stosunkowo niskie współczynniki determinacji (od 0,23 dla Tczewa do 0,36 dla Zawichostu). Nieco lepsze wyniki uzyskano dla związków między GMO i IS, choć w przypadku przekroju w Tczewie równanie jest

Tab. 3. Korelacje miar sezonowości między seriami z badanych przekrojów

Table 3. Correlations of seasonality characteristics between the selected cross-sections

\begin{tabular}{|c|c|c|c|c|}
\hline $\begin{array}{c}\text { Przekroje / Miara } \\
\text { Cross-sections / Characteristic }\end{array}$ & IS & PK & TP0 & GM0 \\
\hline Zawichost - Warszawa N. & 0,927 & 0,749 & 0,975 & 0,913 \\
\hline Zawichost - Tczew & 0,585 & 0,537 & 0,869 & 0,733 \\
\hline Warszawa N. - Tczew & 0,751 & 0,782 & 0,929 & 0,871 \\
\hline
\end{tabular}

Objaśnienia: IS - indeks sezonowości, PK - termin pory koncentracji, TPO - termin połowy odpływu, GMO - wskaźnik sezonowości.

Explanations: IS - seasonality index, PK - period of seasonal concentration, TPO - half-flow date, GMO concentration index. 
istotne, ale jakość dopasowania - niska (ryc. 7). We wszystkich trzech przypadkach funkcją najlepiej aproksymującą był wielomian 2-go stopnia.

\section{Wnioski i dyskusja}

Sezonowa struktura odpływu Wisły, z uwagi na wielkość i fizycznogeograficzne zróżnicowanie jej dorzecza jest zmienna przestrzennie, a ze względu na klimatycznie uwarunkowane, quasi-losowe, zmiany wielkości zasilania i strat bilansowych, zmienia się również w czasie. Zidentyfikowane tu zatem, mniej lub bardziej wyraźne prawidłowości sezonowe i przestrzenne odpływu, mają w efekcie charakter niestały i podobnie jak pory roku i regiony klimatyczne są tworami statystycznymi o słabo poznanym prawdopodobieństwie wystąpienia w czasie i niezbyt precyzyjnie zdefiniowanych granicach przestrzennych. Mimo to identyfikacja tych prawidłowości nie wydaje się działaniem jałowym, gdyż ich opis pozwala na nakreślenie co najmniej ram możliwej zmienności w czasie dziś i w przyszłości oraz przybliżenie kierunków ewentualnych przemian dzisiejszego stanu hydrologicznego poszczególnych części dorzecza. Przeprowadzone niżej analizy sezonowości przepływu Wisły pozwalają na sformułowanie kilku istotnych wniosków:

- mimo ocieplenia oraz obserwowanych i opisywanych w literaturze różnych zmian i oscylacji wielu elementów klimatu Polski i reżimu odpływu naszych rzek (Jokiel, Bartnik 2001; Kaczmarek 2003; Pociask-Karteczka i in. 2003; Woś 2010; Kożuchowski 2011; Stachy 2011; Somorowska, Piętka 2012; Kundzewicz 2013, 2014; Gutry-Korycka i in. 2014; Wrzesiński 2014; Jokiel 2016), jak również dokumentowanych w mniejszej skali efektów gospodarczej działalności człowieka, sezonowa struktura przepływu Wisły nie wykazuje dotąd wyraźnych tendencji, wieloletnich fluktuacji czy zmian dających się opisać i wiarygodnie udokumentować mniej lub bardziej kompleksowymi miarami sezonowości;

- poziom sezonowości przepływu Wisły jest zmienny w czasie i zróżnicowany w zależności od wielkości jej dorzecza, przy czym maleje on z biegiem rzeki wraz ze wzrostem powierzchni i zmianą charakteru jej dorzecza oraz nakładania się na siebie jej reżimu odpływu i reżimów dużych dopływów; ustrój rzeki zmienia się ze złożonego (deszczowo-śnieżnego - w biegu górnym), na prosty (śnieżny dobrze wykształcony - w biegu dolnym);

- średnie indeksy sezonowości przepływu IS Wisły zmieniają się z biegiem rzeki od $32 \%$ do $22 \%$ i są podobne do wartości uzyskanych dla dużych rzek karpackich, wyżynnych i nizinnych (Jokiel 2009, Jokiel, Tomalski 2017b), ale wyraźnie większe (o ok. 10\%) od obliczonych dla dużych rzek pojeziernych (Jokiel, Stanisławczyk 2016); 
- przeciętne wskaźniki sezonowości przepływu GMO w różnych przekrojach Wisły wynosiły od 10 do 15 i były porównywalne z uzyskanymi dla rzek karpackich (11-14) (Soja 2002, Jokiel, Tomalski 2017b); warto podkreślić, że obie wymienione miary IS i GMO ilustrują ten sam aspekt sezonowości;

- w miarę przyrostu powierzchni zlewni Wisły terminy pory koncentracji przepływu (PK) były coraz wcześniejsze (od 185. do 153. dnia roku hydrologicznego), wskazując na stopniową przemianę reżimu odpływu rzeki ze złożonego na prosty, przy czym średnie pory koncentracji w przekrojach górnego biegu Wisły były porównywalne z obliczonymi dla rzek Beskidów Zachodnich, zaś obliczone dla przekrojów dolnych - zbliżone do uzyskanych dla rzek Beskidów Wschodnich (Jokiel, Tomalski 2017b); jednocześnie pory koncentracji przepływu w środkowym i dolnym biegu rzeki były nieco późniejsze (o 10-20 dni) od uzyskanych dla Pilicy, Warty i Bzury (Jokiel 2009);

- średnie terminy połowy odpływu TPO wykazywały podobne do powyższego zróżnicowanie; dość systematycznie malały z biegiem Wisły od 190. dnia do poniżej 170. dnia; dla kilkunastu rzek środkowej Polski Jokiel (2009) uzyskał TPO znacznie wcześniejsze, bo mieszczące się w przedziale od 130. do 170. dnia roku, zaś te same miary obliczone dla 12 rzek karpackich (Jokiel, Tomalski 2016, 2017 b) były liczbowo podobne lub wskazywały na terminy późniejsze (mieściły się w przedziale od 166. do 202. dnia roku hydrologicznego);

- termin pory koncentracji (PK) i termin połowy odpływu (TPO) zdają się opisywać podobny aspekt sezonowości, różniący się jednak od charakteryzowanego przez przedstawione wyżej IS i GMO; obie pary miar można zatem uznać za komplementarne;

-w pięciu analizowanych latach powodziowych indeksy (IS) i wskaźniki sezonowości (GMO) były dość wysokie w górnym biegu Wisły, aby w środkowym i dolnym ustabilizować się na podobnym, zwykle przeciętnym poziomie; natomiast terminy pory koncentracji (PK) i połowy odpływu (TPO) były dość stabilne w całym biegu rzeki, choć bardzo zróżnicowane w obrębie wybranych lat;

- w dwu z trzech lat suchych zmiany badanych miar sezonowości z biegiem Wisły były podobne jak w warunkach przeciętnych; wyraźne różnice wystąpiły w 1959 r., w którym IS były bardzo niskie, a PK i TPO w coraz niżej położonych przekrojach - coraz późniejsze.

\section{Literatura}

Gutry-Korycka M., Sadurski A., Kundzewicz Z.W., Pociask-Karteczka J., Skrzypczyk L., 2014, Zasoby wodne a ich wykorzystanie, Nauka, 1, 77-98.

Jokiel P., 2009, O sezonowym rozmieszczeniu odptywu w wybranych rzekach środkowej Polski, Wiadomości IMGW, 2-3, 15-29. 
Jokiel P., 2016, Sezonowa struktura odptywu rzecznego w środkowej Polsce i jej zmiany w wieloleciu w swietle krzywych sumowych i terminów połowy odptywu, Przegląd Geograficzny, 88(1), 75-86.

Jokiel P., Bartnik A., 2001, Zmiany w sezonowym rozktadzie odptywu w środkowej Polsce w wieloleciu 1951-1998, Wiadomości IMGW, 24 (2), 3-17.

Jokiel P., Bartnik A., 2005, Niektóre problemy zmian $i$ zmienności rocznego hydrogramu przeptywu ræeki na podstawie Pilicy w Præedborzu, Wiadomości IMGW, 2, 5-27

Jokiel P., Stanisławczyk B., 2016, Zmiany i wieloletnia zmienność sezonowości przepływu wybranych rzek Polski, Prace Geograficzne UJ, Kraków, 144, 10-33.

Jokiel P., Tomalski P., 2015, Identyfikacja i analiza sezonów hydrologicznych na przyktadzie dwóch rzek z obszaru środkowej Polski [w:] P. Jokiel (red.), Metody statystyczne w analiwach hydrologicznych środkowej Polski, Wyd. UŁ, Łódź, 201-213.

Jokiel P., Tomalski P., 2016, Zmiany i zmiennośc sezonowej struktury odptywu rzecznego w swietle terminu połowy odptywu, Gospodarka Wodna, 805 (1), 12-18.

Jokiel P., Tomalski P., 2017a, Formy odpływu ræecznego i ich zróznicowanie præestrzenne [w:] P. Jokiel, J. Pociask-Karteczka, W. Marszelewski (red.), Hydrologia Polski, PWN, Warszawa, 160-167.

Jokiel P., Tomalski P., 2017b, Sezonowość odptywu z wybranych zlewniach karpackich, Przegląd Geograficzny, 89 (1), 29-44.

Kaczmarek Z., 2003, The impact of climate variability on flood risk in Poland, Risk Analysis, 23 (3), 559-566.

Kępińska-Kasprzak M., 2015, Susze hydrologiczne w Polsce i ich wphyw na gospodarowanie wodq, Wyd. Naukowe Bogucki, Poznań.

Kożuchowski K., 2011, Klimat Polski. Nowe spojrzenie, PWN, Warszawa.

Kundzewicz Z.W., 2013, Cieplejszy świat. Rzecz o zmianach klimatu, PWN, Warszawa.

Kundzewicz Z.W., 2014, Konsekwencje zmian klimatu dla zasobów wodnych, Monografie Komitetu Gospodarki Wodnej PAN, 20, t. 1, 7-16.

Markham Ch.G., 1970, Seasonality in the precipitation in The United States, Annals of the American Association of Geographers, 3, 593-597.

McCabe G.J., Clark M.P., 2005, Trend and variability in Snowmelt Runoff in the Western United States, Journal of Hydrometeorology, 6, AMS, Boston, 476-482.

Oliver J.E., 1980, Monthly precipitation distribution: a comparative index, Professional Geographer, 32 (3), 300-309.

Pociask-Karteczka J., Limanówka D., Nieckarz Z, 2003, Wpływ oscylacji pótnocnoatlantyckiej na przeptywy rzek karpackich, Folia Geographica, Ser. Geogr.-Phys., 33-34, 89-104.

Soja R., 2002, Hydrologiczne aspekty antropopresji w polskich Karpatach, Prace Geograficzne, IGiPZ PAN, 186, Warszawa.

Somorowska U., Piętka I., 2012, Streamflow changes in mesoscale lowland catchment under future climate conditions, Papers On Global Change, IGBP, 19, 53-65.

Stachý J., 2011, Wystęowanie lat mokrych i posusznych w Polsce (1951-2008), Gospodarka Wodna, $8,313-321$. 
Tomalski P., Tomaszewski E., 2015, Metody, formuty $i$ wory obliczeniowe zastosowane w pracy [w:] P. Jokiel (red.), Metody statystyczne w analiwach hydrologičnych srodkowej Polski, Wyd. UŁ, Łódź, 215-271.

Woś A., 2010, Klimat Polski w drugiej potowie XX wieku, Wyd. Naukowe UAM, Poznań.

Wrzesiński D., 2013, Entropia odptywu rzek w Polsce, Studia i Prace z Geografii i Geologii, 33, Wyd. Naukowe Bogucki, Poznań.

Wrzesiński D., 2014, Detekcja zmian reżimu odpływu rzekw Polsce [w:] T. Ciupa, R. Suligowski (red.), Woda w mieście, Monografie Komisji Hydrologicznej PTG, 2, 319-329.

\author{
Pawet Jokiel \\ Uniwersytet Łódzki \\ Wydziat Nauk Geograficznych \\ Pracownia Hydrologii i Gospodarki Wodnej \\ ul. Narutowicza 88, 90-139 Łódź \\ pawel.jokiel@geo.uni.lodz.pl \\ Przemystaw Tomalski \\ Uniwersytet $€ o ́ d \approx k i$ \\ Wydziat Nauk Geograficznych \\ Pracownia Hydrologii i Gospodarki Wodnej \\ ul. Narutowicza 88, 90-139 Łódz \\ przemyslaw.tomalski@geo.uni.lodz.pl
}


